\begin{tabular}{|c|c|c|}
\hline & International Journal of Current Research in & \\
\hline & $\begin{array}{c}\text { Biosciences and Plant Biology } \\
\text { ISSN: } 2349-8080 \text { (Online) } \bullet \text { Volume } 3 \bullet \text { Number } 4 \text { (April-2016) } \\
\text { Journal homepage: www.ijcrbp.com }\end{array}$ & 要 \\
\hline PUBL & Jour & \\
\hline
\end{tabular}

\title{
Phytoplankton Primary Production in Relation to Limno-chemical Feature in the Context of Fish Yield Potential of Running Water
}

\author{
Brajesh K. Dwivedi* \\ Environmental Sciences Unit, Botany Department, University of Allahabad, Allahabad- 211 oo2, India \\ *Corresponding author.
}

\begin{abstract}
Recent years have a witnessed a growing interest in the use of limno-chemical for water status. Incorporated in the most important laws concerning water management, different key components: hydro-morphological aspects (particularly habitat structures, flow regime, connectivity), physico-chemical parameters, macroinvertebrate and fish assemblages/ potential, biological water quality assessment and ecotoxicological evaluation, depicted potency of water. Studies on phytoplankton primary production in running Ganga water resources during 2013-14 and 2014-2015 revealed that both the gross and net primary productions were more $\left(660.02\right.$ and $\left.414.36 \mathrm{gC} / \mathrm{m}^{2} / \mathrm{y}\right)$ in the first year as compared to second (569.82 and $\left.353.04 \mathrm{gC} / \mathrm{m}^{2} / \mathrm{y}\right)$ year primarily because of favorable climatic and edaphic conditions coupled with more inflow and less outflow in the first year. Community respiration was not varied widely (251.14 and 214.72 $\mathrm{gC} / \mathrm{m}^{2} / \mathrm{y}$ ) in the two years respectively. Primary production showed high correlation with specific conductance, total alkalinity, Chloride, TDS, BOD and total hardness. Potential fish yield was $80 \mathrm{~kg} / \mathrm{ha} / \mathrm{y}$ against the present harvest at $20 \mathrm{~kg} / \mathrm{ha} / \mathrm{y}$ leaving enough scope of augmenting fish production through sustainable management practices.
\end{abstract}

\author{
Article Info \\ Accepted: 05 March 2016 \\ Available Online: 06 April 2016
}

\section{Keywords}

Fish yield potential

Limno-chemistry

Primary production

Running water

\section{Introduction}

Rivers are complex system characterized by intensive spatial and temporal dynamics of the biotic and abiotic conditions. Within the last decades, limnologists have aimed at describing the structure and function of streams; a short review of concept in fresh water/ running water ecology is given (Chovanec, 2000; Pandey and Dwivedi, 2002; Dwivedi and Pandey, 2001; Dwivedi and Pandey, 2002a, b; Dwivedi and Pandey, 2003a, b; Townsend, 1996). As Dwivedi et al. (2012); Dwivedi and Pandey (2015) pointed out, the time is ripe for stream ecologists to use their science more effectively in protecting water resources. The demand was for a more integrated assessment of rivers system that could evaluate the various and wide-reaching impacts of anthropogenic activities on the aquatic environment (Chovanec, 1995;
Dwivedi, 2016a; Dwivedi, 2016b). These activities, including sewage/ wastewater discharge, changes of habitat structure and connectivity aspects, as well as altered flow regimes, are often complex and difficult to describe directly in terms of their ecological concern.

Running water Ganga River is adorned with its impressive reservoir resources having tremendous untapped potentiality. Phytoplankton primary production coupled with systematic study on limno-chemistry could be utilized as indices of trophic status including assessment of fish production potential of such water bodies. Well documentation in this aspect has been made in some tropical Indian reservoirs (Unni and Patil, 1995; Ramakrishniah, 1998). Due to location specificity with wide variations in their morphometry, catchments characteristics, degree of climatic and anthropogenic 
interventions these water bodies are to be studied individually to unravel the problems related to fishing management. This investigation on primary production was made on 48 occasions in even months in emphasizing nature of productivity profiles in relation to limno-chemical features. Fish production efficiency of this reservoir was also out to formulate sound and sustainable management norms for development of this water esteem.

\section{Materials and methods}

\section{Study area}

The study covers stretch of river Ganga from Rasoolabad Ghat, Daraganj Ghat, Ram Ghat, Sangam and Chhatnag Ghat location of Allahabad city areas.

Rasoolabad Ghat - This sampling site is situated at upstream where the river enters into the domain of city of Allahabad. The sources of pollution at this site are cremation, disposal of untreated sewage, washing of clothes, agricultural runoff and temple's solid waste disposal etc.

Daraganj Ghat: It is situated at downstream of Rasoolabad Ghat, on the left bank of the river. This site is known for having big and glorious temples on its bank. Many drains like Salori drain, Govindpur drain, and Mori drain find their way directly near to this site. Other sources of pollution at this site are cattle wallowing, agricultural runoff, mass bathing, dhobi ghat and flower offerings etc.

Ram Ghat: This site is situated at downstream of DaraganjGhat, on the left bank of the river. This site is also known for having many big temples. The main sources of pollutionat this site are open drains carrying untreated domestic sewage from Jhunsi area, religious fairs on its bank, garlands and flower offerings.

Sangam: This site is situated at the confluence point of River Yamuna, Ganga and invisible Saraswati. Because of this rare occurrence, this site is known for the huge fair 'KumbhMela' organized every year due to it's great religious value. People from all over the world come here to have a holy dip. Main source of pollution at this site are mass bathing, flower offerings, cremation activities and religious fairs.

Chhatnag Ghat: At this site river leaves the city and carries water of both the rivers Yamuna and Ganga. This site is situated at the downstream of river Ganga after the Sangam. This site is also used as the crematorial ground. Cattle wallowing are a common picture here. This site also receives untreated sewage and agricultural run-off.

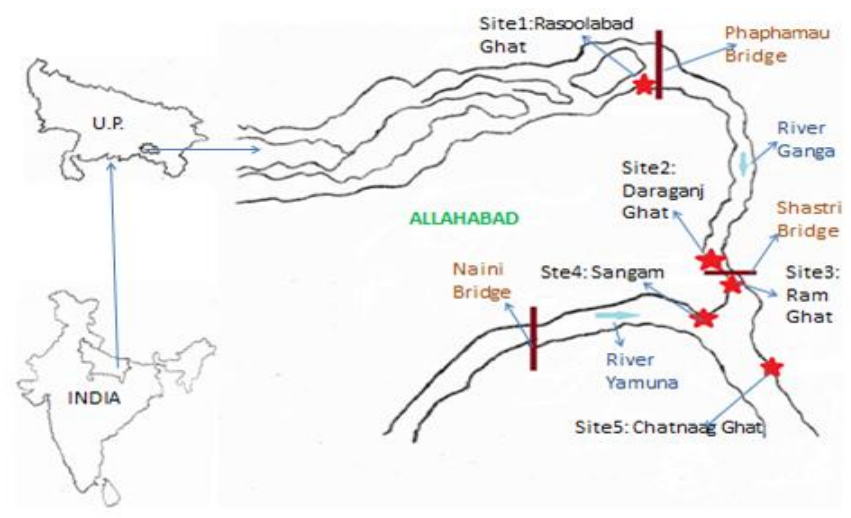

Fig. 1: Map showing five sites along the Ganga River in Allahabad city. Site 1-Rasoolabad Ghat, Site 2- Daraganj Ghat, Site 3- Ram Ghat, Site 4-Sangam and Site 5-Chhatnag Ghat.

\section{Methods}

The experiment involved monthly in situ measurement of primary production for two consecutive years, from August 2013 to July 2014 (first year) and August 2014 to July 2015 (Second year) following Vollenweider (1969) using light and dark bottles. Five sites were selected in the River Ganga of both side (Left- Jhunsi adjoining and Right- Daraganj adjoining), (Fig. 1). The bottles were incubated for $4 \mathrm{~h}$ between 10.00 and 14.00 hours. Dissolved oxygen was estimated immediately after exposure by Winkler's method. Average hourly rates were multiplied by the hours of sunshine to get the daily rates. Estimation of per unit surface area for primary production as well as community respiration was made by integrating the values obtained at different depths of the water column starting from immediate subsurface followed by $1 \mathrm{~m}, 2 \mathrm{~m}, 3 \mathrm{~m}$ and $4 \mathrm{~m}$ below from the surface. Annual measurements were calculated by sunning up the monthly values and phyisco-chemical features of water were determined as per standard methods (APHA).

\section{Results and discussion}

\section{Environmental character}

The water channels (river) started filling by the end of June or early July due to rains in reaching its maximum water level of $29.00 \mathrm{~m}$ by the end of August and early September. Water level was not stabilized in subsequent 
post- monsoon months due to heavy draw down by irrigation project as well as through irrigation canal.

The water channel received lesser inflow $\left(1600.08 \times 10^{6}\right.$ $\mathrm{m}^{3}$ ) in the second year as compared to favorable inflow $\left(2311.27 \times 10^{6} \mathrm{~m}^{3}\right)$ in the first year when water level touched the FRL (Fig.1a). Water temperature at the surface varied sinusoidally ranging between $32.0^{\circ} \mathrm{C}$ with summer high and monsoon/winter low. Transparency showed clear seasonality due to erratic rainfall in the second year and gravelly soil character in the catchment (Fig.1b). Secchi disc depth recorded minimum at $1.05 \mathrm{~m}$ and maximum at $2.64 \mathrm{~m}$ with an overall mean at $2.04 \mathrm{~m}$. Thus the euphotic zone extended between 3.0 and $6.0 \mathrm{~m}$. Moderately rich electrolyte (Mean specific conductance; $196.60 \mathrm{uS} / \mathrm{cm}$ ) with $\mathrm{pH}(8.07)$, total alkalinity (mean: 168.46), total hardness (mean118.55), chloride (mean 27.49), TDS (mean 216.83), DO (mean6.4) and BOD (mean9.41 mg/l) were characteristics of this water channel (Table 1) and encountering with nutrients with reference to seasonal variations (Figs. 2 to 10). The nutrient regime and hydrological status were depicted moderate with the enrichment observed during monsoon as well as in some summer months signifying moderate productivity of this water channel.

\section{Primary production}

\section{Gross primary production (GPP)}

Vertical profile of gross primary production showed marked monthly fluctuation at all the site with single or bimodal peak. Single peak was observed in 2013-14 during September, December, January, March and June; single but extended peak was noticed in February, November, May and July. One the contrary, dichotomous profiles with more than one maxima were common in August, September, October, January April, May, June and July. With some modifications, the vertical depth profiles in 2013-14 with single peak was noticed only in February; single but extended peak was more prominent in September, November, December, January and February. Dichotomous profiles with more than one maxima were found in August, September, October, December, January and March (Table 2).

Sub surface maxima occurred in most cases (41 out of $48)$ at 1.0 and $3.0 \mathrm{~m}$ depth, and 2.0 and $3.0 \mathrm{~m}$ depth from the surface in the first and second year respectively suggesting evidence of surface photo inhibition as also observed by Dokulil et al. (1988). Same was also true in case of Manchanbele reservoir (MBR), CB reservoir, near Bangalore, Karnataka where sub-surface maxima were encountered in 17 out of 26 experiments (Krishna Rao et al., 1999). Some of the depth profiles were characterized by lower production per unit area and some were with extended area having substantial production per unit area. Thus, hourly integrated gross production $\left(\sum \mathrm{A}\right)\left(\mathrm{mgC} / \mathrm{m}^{2} / \mathrm{h}\right)$ exhibited wide variations from August to July to the tune of 148 and $298.22 \mathrm{mg}$ (mean: 230.98) and, 164.99 and $291.9 \mathrm{mg}$ (mean: 194.83) in the first and second year respectively. The daily integral production $\left(\sum \sum \mathrm{A}\right)\left(\mathrm{mgC} / \mathrm{m}^{2} / \mathrm{d}\right)$ fluctuated between 1198 and 2389 and, 1318 and $2342 \mathrm{mg}$ in the first and second year respectively with an annual mean of 1855 and $1565 \mathrm{mg}$ in those two years respectively.

Thus, there was change in the shape of the vertical profiles encountered during first and second year. In the first year, the profiles were characterized by higher production per unit area in contract to lower production per unit area in the second year with the absence of marked maxima and truncated distribution (as depicted from Fig. 11a) when the reservoir received poor inflow.

Gross primary production exhibited distinct seasonality with increasing trend during post-monsoon months (October-January) in both the years and troughs in monsoon (August-September) and early pre-monsoon (April-May) periods. Temporal changes of primary production in tropical lakes as designed Melack (1976) are water channels were showed (i) well defined seasonal fluctuations caused by rains or vertical mixing, (ii) narrow seasonality and (iii) abrupt changes with narrow seasonality. Though, Indian reservoirs exhibiting all the three patterns of production. Ganga River showed the first type where low photosynthetic rate were observed in monsoon as influenced by rain with the dilution of nutrients and in early pre-monsoon with low phytoplankton density due to low nutrient content. The temporal and spatial variation in Amax, the light saturated rate of photosynthesis, which is an indicator of the capacity of a water bodies are to produce and sustain algae (Westlake, 1980). In the 1st year, Amax maintained markedly and consistently higher rate than the second year, probably due to higher algal biomass in the first year. The maximum values of Amax $\left(\mathrm{mgC} / \mathrm{m}^{3} / \mathrm{h}\right)$ were recorded in June in first year were 110.50 and 102.93 in Jhunsi adjoining (JA) and Daraganj adjoining (DA), respectively coinciding with the highest plankton density (Singh and Das, 2002) in this month. In the second year, Amax was maximum in June at the DA (93.75) and January at the JA (75.00). 
Table 1. Site wise results of the physico-chemical parameters of river Ganga at Allahabad city (During 2013 June, 2013- May, 2015).

\begin{tabular}{|c|c|c|c|c|c|c|c|c|c|c|c|c|c|c|c|c|c|c|}
\hline \multirow[t]{2}{*}{ Parameter } & \multicolumn{3}{|c|}{$\begin{array}{l}\text { Site 1: Rasoolabad } \\
\text { Ghat }\end{array}$} & \multicolumn{6}{|c|}{ Site2:Daraganj Ghat Site3:Ram Ghat } & \multicolumn{3}{|c|}{ Site4:Sangam } & \multicolumn{3}{|c|}{ Site5:Chhatnag Ghat } & \multirow[t]{2}{*}{ Avg. $\pm S D$} & \multirow{2}{*}{$\begin{array}{l}\text { Permissible } \\
\text { limit }\end{array}$} & \multirow[t]{2}{*}{ Standards } \\
\hline & $\mathbf{S}$ & $\mathbf{R}$ & W & $\mathbf{S}$ & $\mathbf{R}$ & W & $\mathbf{S}$ & $\mathbf{R}$ & W & S & $\mathbf{R}$ & W & $\mathbf{S}$ & $\mathbf{R}$ & W & & & \\
\hline Temp. $\left({ }^{\circ} \mathrm{C}\right)$ & 31.3 & 28.6 & 26.2 & 32.5 & 28.5 & 25.7 & 30.8 & 27.6 & 24.6 & 30.9 & 25.2 & 24.2 & 31.2 & 27.5 & 25.7 & $28.03 \pm 2.66$ & - & - \\
\hline $\mathrm{pH}$ & 8.8 & 7.6 & 8.2 & 8.2 & 7.5 & 8.0 & 8.5 & 7.4 & 8.1 & 8.7 & 7.5 & 8.4 & 8.2 & 7.6 & 8.3 & $8.07 \pm 0.44$ & & $\mathrm{AS}^{15}$ \\
\hline $\mathrm{EC}\left(\mu \mathrm{mho}-\mathrm{cm}^{-1}\right)$ & 220.6 & 296.0 & 197 & 188.7 & 278 & 145.9 & 129.9 & 245.6 & 119.2 & 129.3 & 256.3 & 100.6 & 147.9 & 249.65 & 122.7 & $188.49 \pm 63.0$ & 300 & \\
\hline $\mathrm{DO}(\mathrm{mg} / \mathrm{L})$ & 4.7 & 5.7 & 6.05 & 6.0 & 6.4 & 7.0 & 6.3 & 6.9 & 7.1 & 5.4 & 6.1 & 7.9 & 6.9 & 7.1 & 7.5 & $6.47 \pm 0.82$ & $4.0-6.0$ & PHS \\
\hline $\mathrm{BOD}(\mathrm{mg} / \mathrm{L})$ & 12.6 & 11.9 & 9.2 & 10.4 & 8.7 & 7.8 & 10.1 & 9.2 & 8.7 & 10.2 & 8.9 & 8.6 & 9.4 & 8.4 & 7.0 & $9.41 \pm 1.41$ & 5.0 & USPHS \\
\hline $\mathrm{COD}(\mathrm{mg} / \mathrm{L})$ & 22.5 & 19.5 & 18.2 & 16.2 & 15.7 & 13.5 & 16.9 & 15.4 & 14.8 & 15.6 & 14.3 & 12.7 & 11.9 & 11.1 & 10.9 & $15.28 \pm 3.07$ & 4.0 & USPHS \\
\hline $\mathrm{TH}(\mathrm{mg} / \mathrm{L})$ & 183.0 & 177.2 & 112.0 & 199.4 & 163.7 & 127.4 & 114.6 & 96.5 & 89.6 & 101.3 & 92.7 & 67.9 & 99.6 & 83.2 & 70.2 & $118.55 \pm 40.9$ & 500 & $\mathrm{WHO}^{16}$ \\
\hline $\mathrm{TA}(\mathrm{mg} / \mathrm{L})$ & 189.3 & 154.9 & 176.2 & 169.6 & 150.7 & 161.2 & 180.3 & 152.9 & 164.7 & 185 & 154.7 & 182.7 & 167.5 & 157.8 & 179.4 & $168.46 \pm 12.5$ & - & - \\
\hline $\mathrm{Cl}^{-}(\mathrm{mg} / \mathrm{L})$ & 60.8 & 12.6 & 27.6 & 54.2 & 11.6 & 22.2 & 47.2 & 10.9 & 19.0 & 51.13 & 11.5 & 21.1 & 33.7 & 10.9 & 17.9 & $27.49 \pm 16.97$ & 250 & USPHS \\
\hline TDS(mg/L) & 237.0 & 245.0 & 230.0 & 220.0 & 225.0 & 218.0 & 202.0 & 214.0 & 196.0 & 228.0 & 212.0 & 201.0 & 215.0 & 199.0 & 210.5 & $216.83 \pm 13.84$ & 500 & USPHS \\
\hline
\end{tabular}

Table 2. Some selected production profile with depth in Ganga River at Allahabad city: Gross Primary Production $\left(\mathrm{mgC} / \mathrm{m}^{2} / \mathrm{h}\right)$.

\begin{tabular}{|c|c|c|c|c|c|}
\hline \multicolumn{6}{|c|}{ (2013-14) } \\
\hline Depth & Site-1 & Site-2 & Site-3 & Site-4 & Site-5 \\
\hline 0 & 20 & 28 & 32 & 48 & 55 \\
\hline 1 & 24 & 45 & 40 & 38 & 75 \\
\hline 2 & 40 & 45 & 45 & 44 & 50 \\
\hline 3 & 22 & 35 & 55 & 58 & 38 \\
\hline 4 & 18 & 25 & 24 & 24 & 38 \\
\hline 5 & - & - & - & - & - \\
\hline \multicolumn{6}{|c|}{ (2014-15) } \\
\hline Depth & Site-1 & Site-2 & Site-3 & Site-4 & Site-5 \\
\hline 0 & 40 & 44 & 46 & 40 & 40 \\
\hline 1 & 45 & 38 & 40 & 64 & 45 \\
\hline 2 & 74 & 42 & 48 & 40 & 38 \\
\hline 3 & 42 & 44 & 42 & 60 & 63 \\
\hline 4 & 22 & 38 & 40 & 12 & 42 \\
\hline 5 & - & - & - & - & - \\
\hline
\end{tabular}


Table 3. Annual primary production and community respiration in Ganga River.

\begin{tabular}{lllll}
\hline & & GPP & NPP & CR \\
\hline $2013-14$ & $\mathrm{gC} / \mathrm{m}^{2} / \mathrm{y}$ & 660.02 & 414.36 & 251.14 \\
$2014-15$ & $\mathrm{gC} / \mathrm{m}^{2} / \mathrm{y}$ & 569.82 & 353.04 & 214.72 \\
\hline
\end{tabular}

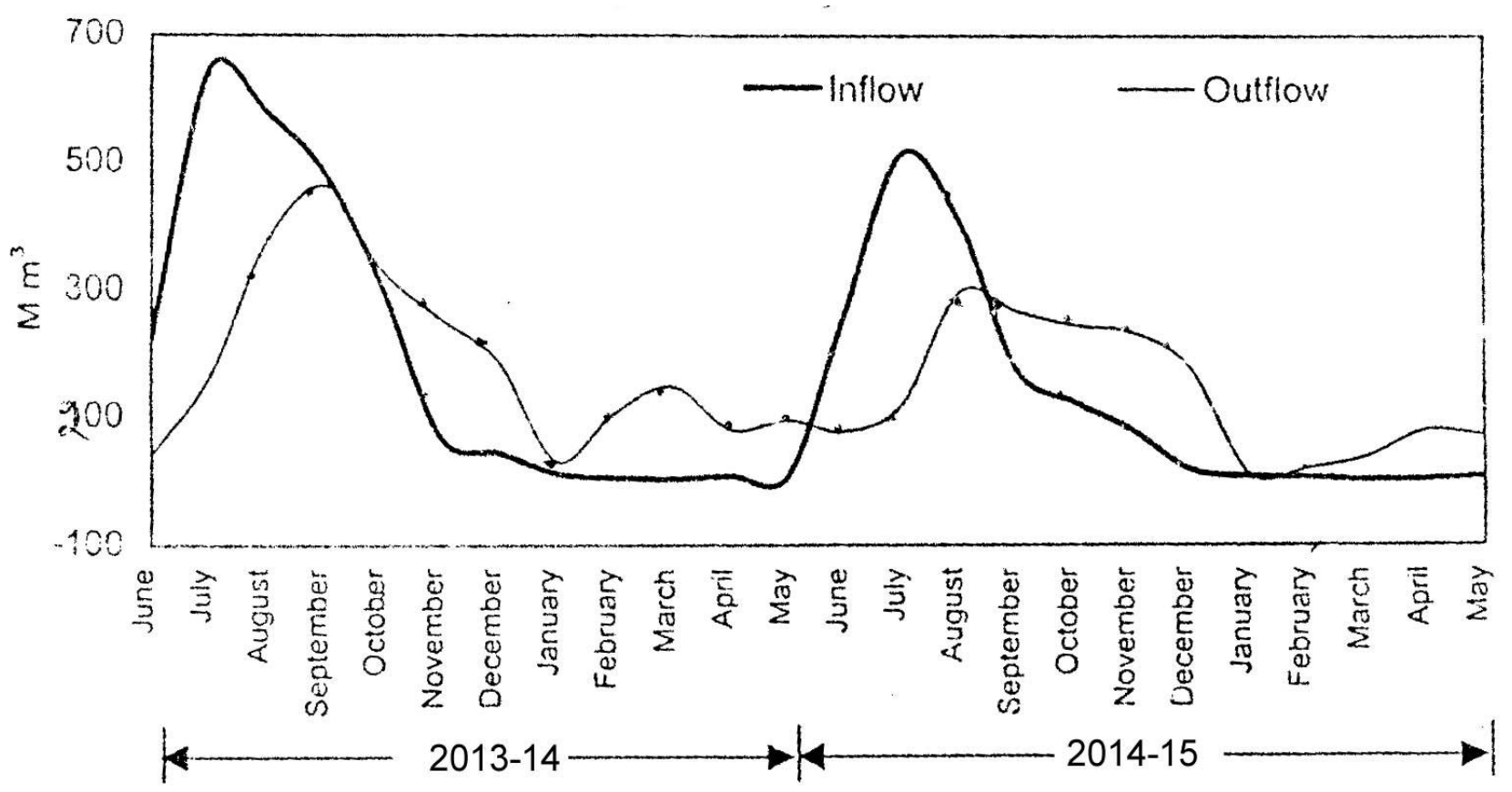

Fig. 1a: Average inflow and outflow in river Ganga (2013-15) at Allahabad city.

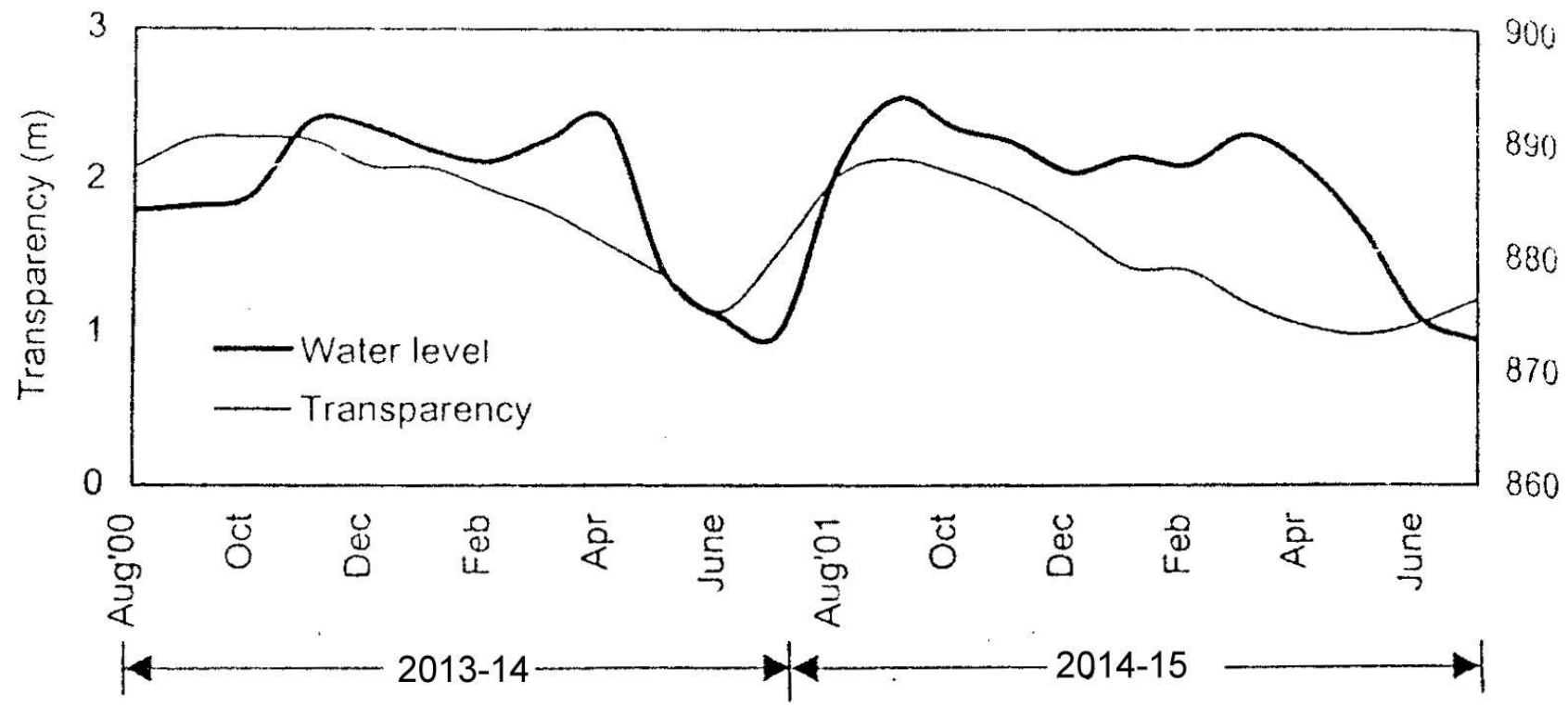

Fig. 1b: Temporal variation in water level and transparency in river Ganga. 


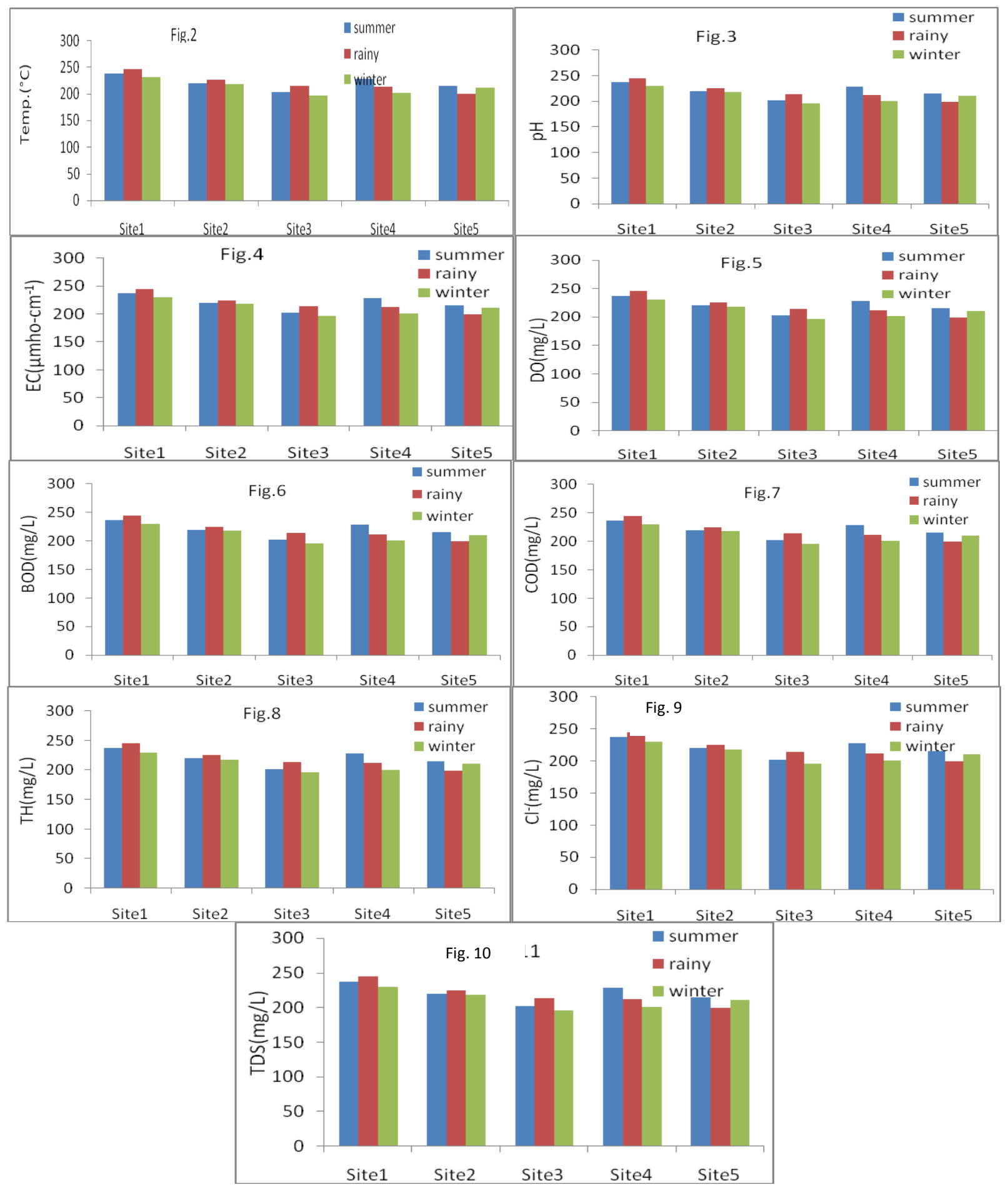

Figs 2-10: Seasonal variations in physico-chemical parameters of river Ganga at Allahabad city (During 2013 June, 2013- May, 2015). 

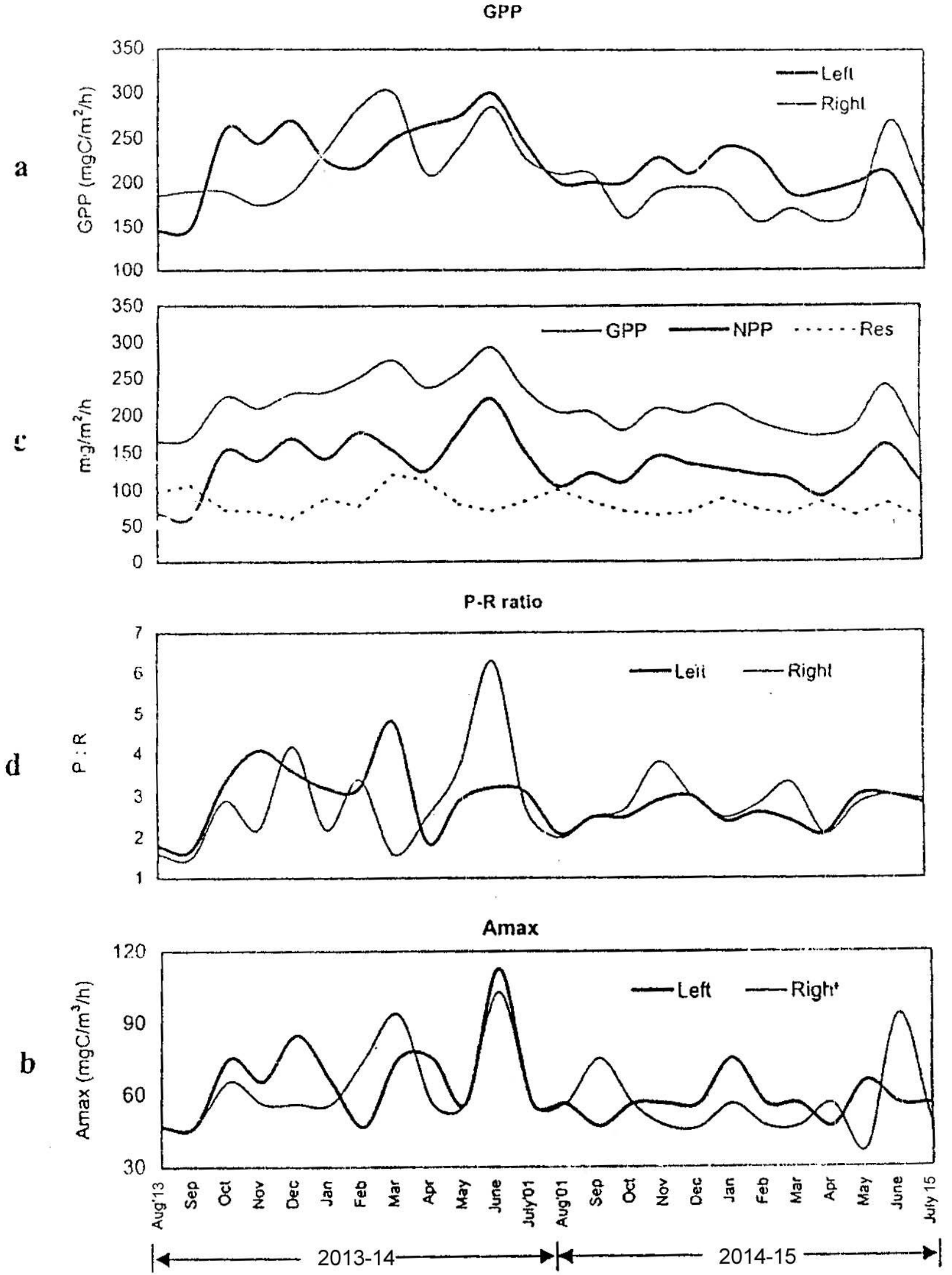

Fig. 11: Temporal variations of GPP, NPP, P:R and Amax in river Ganga at Allahabad city (Left- Jhunsi adjoining site, RightDaraganj adjoining). 


\section{Net primary production (NPP)}

The average hourly net primary production $\left(\mathrm{mgC} / \mathrm{m}^{2} / \mathrm{h}\right)$ varied widely from 61.9 to 221.9 and 89 to 160 in the first and second year respectively and was distributed over a much narrower depth than gross production. The average annual net production was 144.92 and $120.98 \mathrm{mgC} / \mathrm{m}^{2} / \mathrm{h}$ in the first and second year respectively (Fig. 11c).

\section{Community respiration $(\mathrm{CR})$}

The rates of respiration in the euphotic zone were in higher side during August, September, January (DA), March (DA), April and May (JA) in the first year and August, January, April and June (DA) in second year. The average $\mathrm{CR}$ was higher in the first year $\left(86.66 \mathrm{mgC} / \mathrm{m}^{2} / \mathrm{h}\right)$ as compared to second year $(73.95$ $\mathrm{mgC} / \mathrm{m}^{2} / \mathrm{h}$ ) (Fig. 11c). The community respiration rate at site-5 reservoir signifies the dominance of autorophic food chain rather than heterotrophic one (Singh and Das, 2002).

\section{P-R ratio}

Odum (1956) designed the idea of determining P-R ratio in order to define a community type and also the concept of autotrophy and heterotrophy. The P-R ratio fluctuated widely to the tune of 1.6 to 4.2 in 2013-14 than the second year 2.0 to 3.3. The ratio varied greatly with seasons, higher values in post-monsoon and late summer (Fig. 11d). The trough in monsoon was due to dilution effect of nutrients getting reflected in the low phytoplankton density. Same was true in early pre-monsoon also with low population of phytoplankton community (Singh and Das, 2002). In productive waters P-R ratio remains low. In this study, the annual mean of this ration was around 2.6, suggesting that the water body was moderately productive.

\section{Annual primary production and energy transformation}

Data on annual primary production (Table 3) computed from the average daily rates indicated that both GPP and NPP varied greatly in both the years. The values were 660.02 and $414.36 \mathrm{gC} / \mathrm{m}^{2} / \mathrm{y}$ in the first year and $569.82 \& 353.04 \mathrm{gC} / \mathrm{m}^{2} / \mathrm{y}$ in the second year. Energy in the form of photosynthetic primary production was estimated to be $66.17 \times 10^{6}$ and $56.98 \times 10^{6} \mathrm{Kcal} / \mathrm{ha} / \mathrm{y}$ in this river channel with assimilation efficiencies $61.98 \%$ and $61.91 \%$ in 2013 14 and 2014-15 respectively.

\section{Fish production potential}

The very basis of water channel management for augmenting fish production sustainably is to predict fish yield potential. Several indices have been proposed time to time to correlate fish yield to physical, chemical as well as biological feature (Henderson, 1973; Shiddamallayya and Pratima, 2008). However, each model has its own limitation in prediction in a particular situation (DeSilva, 1992). Mc Connel et al. (1977) found the conversion efficiency from GPP to fish yield in the range between 0.1 and $1.6 \%$ in natural waters. At present, in river Ganga, with provisional management, the maximum fish harvest was $20 \mathrm{~kg} / \mathrm{ha} / \mathrm{y}$ amounting a total of $70 \mathrm{t}$ of fish catch annually.

The yield potential estimated through GPP provides a fairly dependable limnological guide to fish productivity in Indian reservoirs. The targeted potential fish yield (TPFY) estimated through Melack's model (Melack, 1976), MDI (Ramakrishniah, 1990) and biomass calculations (Waldichuk, 1958) were 36,25 and $140 \mathrm{~kg} / \mathrm{ha} / \mathrm{y}$ respectively. Assuming a judicial conversion efficiency of $0.2 \%$ GPP, the TPFY of river Ganga would be around $80 \mathrm{~kg} / \mathrm{ha}$. Fish conversion efficiency from GPP based on present landings of fish would have given the real conversion efficiency of the target water bodies. At present $20 \%$ of TPFY is being harvested from Ganga River. So, there is still enough scope of increasing fish production even up to 55-65\% of TPFY, which could be achieved easily through scientific management norms.

\section{Conflict of interest statement}

Author declares that they have no conflict of interest.

\section{Acknowledgement}

The author is extremely grateful to the Co-ordinator, Environmental Science Unit, Botany Department, University of Allahabad, for the support and encouragement during the course of this work. 


\section{References}

APHA, AWWA and WPCT, 2007. Standard Methods for Examination of Waste Water. $21^{\text {st }}$ Edn. American Public Health Association Waterworks Association and Water Pollution Control Fedration, New York.

Chovanec, A., Jager, P., Jungwirth, M., Koller-Kreimel, V., Moog, O., Muhar, S., Schmutz, S. 2000. The Austrian way of assessing the ecological integrity of running waters: A contribution to the EU Water Framework Directive. Hydrobiologia. 422/423, pp. 445-452.

De Silva, S.S., 1992. In reservoir Fisheries of Asia. (Ed.: DeSilva, S.S.). IDRC, Canada. p.12.

Dokulil, M., Bauer, K and Silva, E. L., 1983. In: Limnology of Parakrama Samudra, Sri Lanka- A Case Study of an Ancient Man-made Lake in Tropics (Ed.: Schiemer). Den. Hydrobiol. p.12 and p.85.

Dwivedi, B.K., Pandey, G.C., 2001. Seasonal dynamics of cyan bacterial toxin producing algal species of two water ponds. Aquacult. 2, 141-146.

Dwivedi, B.K., Pandey, G.C., 2002a. Physico-chemical factors and algal diversity of two ponds (Girija Kund and Maqubara pond) Faizabad. Poll. Res. 21(3), 365374.

Dwivedi, B.K., Pandey, G.C., 2002b. Length-weight relationship and relative condition factors of Labeo rohita and Catla catla in cyanotoxin environment and its mitigation through photosynthetic bacteria. Proc. Zool. Soc. India. 1, 9-16.

Dwivedi, B.K., Pandey, G.C., 2003a. Complex dynamics of toxin producing algal species and primary productivity in two water ponds of Faizabad. Env. Biol. 24(1), 55-61.

Dwivedi, B.K., Pandey, G.C., 2003b. An approach to improve water quality through photosynthetic bacteria. Nature Environ. Poll. Technol. 2(2), 145-152.

Dwivedi, B.K., Tiwari, S.P., Prihar, D.K., 2012. Biological surveillance of running water at Allahabad city. Bioherald 2(1), 35-40.

Dwivedi, B.K., Pandey, G.C., 2015. Hydrochemical assesssment of the pollutants in ground waters of Allahabad city. Adv. Res. Technol. 3(4), 26-35.

Dwivedi, B.K., 2016a. Occurrence of cyanotoxins and their removal by oxygen evolving bacteria with implication to fish productivity. Int. J. Curr. Microbiol. Appl. Sci. 5(3), 36-47.

Dwivedi, B.K., 2016b. Ecological integrity of river water quality: in relation to primary productivity and cyanotoxin occurrence. Adv. Res. Biol Sci. 3(3), 24-34.
Henderson, H.E., Ryder, R. A., Kudhongania, A. W., 1973. Assessing fishery potentials of lakes and reservoirs. J. Fish. Res. Bd. Can. 30, 2000-2009.

Krishna Rao, D.S., Das, A.K., Kartikeyan, M., Ramakrishniah, M., 1999. Ecofriendly management of resources for doubling fish production- strategies for $21^{\text {st }}$ century. Proc. National Seminar (Eds.: Sinha, M., Kumar, D., Kathiha, P.), 22-23 December, 1999, IFSI, Barrackpore. p.1.

Krishna Rao, D.S., Shakuntla, K., 1999. Phytoplankton primary production and fish production potential of Neligudda reservoir (Bangalore, south India). Proc,Nat.Acad. Sci.69 (B, III \& IV), 283-297.

Mateos, M.T., Carcedo, S.G., 1988. Influence of heavy metals on soil oxidoreductase. Biol. Agric. Horticul. 5, 135-142.

McConnel, W. J., Lewis S, Olsen, J.E., 1977. Gross photosynthesis as an estimator of potential fish production. Trans. Am. Fish. Soc. 106, 417-423.

Melack, J.M., 1976. Primary productivity and fish yields in tropical lakes. Transact. Amer. Fish. Soc. 105, 575-580.

Odum, H.T., 1956. Primary production in flowing waters. Limnol. Oceanogr. 1(2), 102-117.

Padey, G.C., Dwivedi, B.K., 2002. The toxins of cyanobacteria: Emerging water quality problem. In: Ecology of Polluted Water (Ed.: Kumar). Asish Publishing House, New Delhi. pp.395-405.

Ramkrishniah, M., 1990. In Morpho-drainage Index, a fish yield predictor for Indian reservoir. Paper presented at the $2^{\text {nd }}$ Asian Reservoir Workshop (Ed.: Hang Zhou). P.R. China.

Ramkrishniah, M., Krishna Rao, D.S., Sukumaran, P.K., Das, A.K., 2000. Ecology and fish yield potential of selected reservoir of Karnataka. Bull. No. 94, CIFRI, Barrackpore, West Bengal. p.41.

Shiddamallayya, N., Pratima, M., 2008. Impact of domestic sewage on fresh water body. J. Environ. Biol. 29(3), 303-308.

Singh, D. N., Das, A. K., 2002. Proc. Seventy second Annual Session, National Science Academy of Sciences, India, 25-27 October, NEHU, Shilong, Abstract no. 37.

Townsend, C., 1996. Concept in river ecology: pattern and process in the catchment hierarchy. Arch. Hydrobiol. Suppl. 113, Large Rivers. 10, 3-21.

Unni, K.S., Patil, M.K., 1995. Thermal stratification, eutrophication and primary production in a central Indian reservoir. In: Tropical Limnology (Eds.: Timotius, K. H., Gottenboth, F.). pp.291-229. 
Vollenweider, R.A., 1969. A Manual of Method for Measuring Primary Productivity in Aquatic Environment, IBP Hand Book No.12. Blackwell Scientific Pub., U.K. 213p.
Westlake, D.E., 1980. The Functioning of Fresh Water Ecosystem (Eds.: Le Cren, E.D., Lowe Mc Connel, R.H.). Cambridge University Press, Cambridge. p.141.

\section{How to cite this article:}

B. K. Dwivedi, 2016. Phytoplankton primary production in relation to limno-chemical feature in the context of fish yield potential of running water. Int. J. Curr. Res. Biosci. Plant Biol. 3(4), 106-115. doi: http://dx.doi.org/10.20546/ijcrbp.2016.304.015 